UDC 347.4

DOI https://doi.org/10.32849/2663-5313/2021.9.02

\title{
Petro Guyvan,
}

PhD in Law, Honored Laweyer of Ukraine, Professor, Poltava Institute of Business, 7, Sinna street, Poltava, Ukraine, postal code 36000, lawiur01@rambler.ru

ORCID: orcid.org/0000-0003-3058-4767

Guyvan, Petro (2021). Essential characteristics of non-jurisdictional methods of legal protection: temporal aspect. Entrepreneurship, Economy and Law, 9, 11-17, doi: https://doi.org/10.32849/ 2663-5313/2021.9.02

\section{ESSENTIAL CHARACTERISTICS OF NON-JURISDICTIONAL METHODS OF LEGAL PROTECTION: TEMPORAL ASPECT}

Abstract. The purpose of the research is to study the essential and temporal features of nonjurisdictional ways to protect the violated civil law; establish temporal criteria of protective capacity of the right different from the time of realization of the claim. Research methods. The author used general scientific and special-scientific methods of cognition which allow considering temporal factors as elements of subjective substantive law and legal relations in general and determining their position in the system of protective mechanism of civil law. Results. The main doctrinal concepts concerning the principles of applying such measures of influence on the offender as self-defense and the use of operational protective equipment are studied. It has been established that the non-jurisdictional means have such legal support as a person's appeal to a court. This power consists of a set of actions of the holder of the violated subjective civil law aimed at terminating the violation or other protection without recourse to the competent authority of the state. However, in the temporal context, the legal standardization has various character, and the statute of limitations is not applied for determination of term of protection in similar character. It is important for self-defense to waver at the time of the offense, and it is necessary to follow the general principles of good faith and reasonableness for operational sanctions, since the law in most cases does not set the time of their implementation. In this regard, some aspects of the application of such operational actions as withdrawal from the contract, unilateral change, or termination of the legal relationship at the will of the creditor are considered. It is only important that the plaintiff has the authority to perform these actions, that is, in other words, such authority should be reflected in the law or agreement. It is also necessary that these actions were within the time limit of adequate response. Conclusions. The article concludes that the time limits for the exercise of these powers must be established by law. In particular, the legal act should indicate the need to take relevant precautionary actions within a reasonable period from the moment of detection of the violation and the limited duration of the existence of these powers. The time of the specific security powers should be reasonable but not exceed the duration of the violation.

Key words: reasonable term, statute of limitations, operative protection.

\section{Introduction.}

The appeal of the entitled person to the competent authorities of the state with a request to protect the violated or disputed right is one of the most effective means of protection for the holders of subjective civil rights. The possibility of law enforcement is part of the subjective substantive right to sue. The purpose of a subjective right is that the subject could legally, within the limits of the powers granted to him by the objective law, take actions aimed at meeting his own needs. At the same time, the judicial method of protection of the violated civil right is not the only option for exercising the right to protection (Kostruba, 2014, p. 116). Moreover, the state cannot always provide compulsory protection of rights promptly and in a form acceptable to society. Thus, the statutory obligation of the state to exercise the protection of subjective rights of the individual does not preclude the use of other more mobile protection mechanisms. In the literature, the opinion was expressed that the application of the protected person for protection to the state competent authority occurs only in the case when the measures of self-protection did not give positive results (Eliseikin, 1975, p. 10). It is hardly possible to agree with this point of view, as self-defense of the law and other extrajudicial means of its protection are quite autonomous. Moreover, it is unacceptable that the possibility of applying these protective measures only when the violation or danger to subjective civil law could not be eliminated by other protec- 
tive means. After all, Art. 20 of the CCU clearly states that the exercise of the right to protection is exercised by a person at his discretion (Antonyuk, 2004, p. 13). This norm should be understood as the fact that a person has the right to decide not only on the issue of protection or refusal but also choose the appropriate form and method.

2. Legal substantiation of non-judicial methods of protection of the right.

After violating a person's subjective civil right, he is free to choose a judicial or non-judicial (non-jurisdictional) form of protection, the method of protection. This authority is a set of actions of the holder of the violated subjective civil right aimed at terminating the violation or other protection without recourse to the competent authority of the state. Powers covered by a non-jurisdictional method of legal protection are divided into the right to prompt influence on the offender and self-defense. Although the plaintiff is legally authorized to choose the method of protection, such a choice in a non-jurisdictional format is often limited, because, as a rule, the means of protection of civil rights are inextricably linked with the nature of the right being protected. Thus, in the protection of property rights, the actions of the actual order can be carried out - self-defense in the form of necessary defense, etc., and in the implementation of protective obligations, operational measures of influence seem the most appropriate and adequate.

At the same time, the law, providing for such methods as self-defense of subjective rights, application of operational measures by the authorized person, etc., mostly does not regulate their temporal factors, does not specify the terms limiting actions of the person the right belongs to. According to the legislator, the actions must lawful and consistent with the nature of the most protected substantive law. The same can be said for other non-judicial means of protecting violated civil rights. For example, in accordance with Art. 17 of the Civil Code of Ukraine, the protection of civil rights and interests may be exercised by the President of Ukraine, state authorities, authorities of the Autonomous Republic of Crimea or local governments within their own powers. In this situation, unless otherwise provided by legislation defining the scope of these powers, the protection of rights in the administrative order is not limited in time.

As it has been convincingly proven in the literature, the term is an integral and essential element of subjective right (Guyvan, 2014, p. 21-22; Guyvan, 2021, p. 108), it should be recognized that the duration of the creditor's protective powers to self-defense or operational influence on the offender should be determined based on general legal principles of reasonableness and good faith. In other words, the temporal characteristics of substantive law, without which it cannot exist, for these relations are determined each time by the participants themselves following the nature and scope of the protective action, the order of its commission, etc. In the author's opinion, this approach of the legislator is unjustified, as it allows for broad subjectivity in assessing the correctness of the application of the mentioned measures. Moreover, since the misapplication of non-judicial protective measures against a defaulting debtor can be challenged in court (Guyvan, 2004, p. 37-38), legal uncertainty on this issue gives rise to law enforcement differences. Therefore, this section will explore the issue of temporary regulation of out-of-court remedies.

Demonstrative application of means of protection of the violated right by the right holder is the operative influence on the violator of civil law provided by the legislation of Ukraine. Let's first consider the issues related to the legal nature of this remedy. In modern civilization, there is almost no dispute about the existence and statutory consolidation of such a specific form of civil protection of the violated subjective right as the application of a counterparty that improperly fulfills its obligations, the impact of operational nature aimed at eliminating illegally achieved the offender results or to prevent him from achieving such results. It has already been mentioned that their principal feature is the exercise of the protection powers enshrined in the legislation or the contract by the holder of the violated right without recourse to the authorized body of the state. However, the application of such types of influence on the infringer does not eliminate the possibility of the obligated person to appeal their application to a court or a commercial court. Thus, it is clear that by granting the creditor some protection and legal powers or authorizing their dispositive establishment, the state provided the possibility of coercion against the defaulting debtor by unilateral actions of the commissioner.

Given the above nature of the relevant interactions of the participants of the protective obligation, domestic legal science has had and still has lively discussions about the relations between operational influence and state coercion. Thus, B.B. Cherepakhin put forward the thesis that the concept of the right to sue in a broad sense covers any claims of the authorized person presented to the offender both in court and another order to protect his violated right. In this case, this definition is also applied to the implementation of measures of operational influence on the violator, when 
the authorized person is given the right to independently ensure the fulfillment of the security obligation (Cherepakhin, 1964, p. 72). This thesis is embodied in the works of A.A. Dobrovolsky that the lawsuit is used as a procedural remedy in both judicial and non-judicial bodies (Dobrovolsky, 1965, p. 5). Modern researchers have developed this concept. In particular, they note that self-defense is a form of state coercion, which characterizes another qualitative state of such coercion, the possibility of which supports the exercise of every subjective right and the fulfillment of every legal obligation (Basin, 2003, p. 421). Understanding the system of measures provided by law, which are based on state coercion and aimed at ensuring the inviolability of rights, elimination of offenses, as protection (Lyashevska, 2018, p. 112), these researchers concluded that signs of state coercion occur in both jurisdictional protection and self-defense.

The author cannot support this legal approach. The concept of state and non-state coercion has long been divided in scientific works (Karkhalev, 2009, p. 70). From this point of view, it is quite fair to say that measures of operational influence on the defaulting debtor do not require the use of state coercion. Thus, the application of the latter, firstly, is ensured by the involvement of a special competent state law enforcement agency, and secondly, the mechanism of such application is regulated by relevant procedural law, while coercion as a result of individual protective action of the right holder is much more efficient and less cumbersome. procedural point of view. From a temporal point of view, this approach also deserves critical appraisal, as such a construction could necessitate the application of the statute of limitations on claims that are implemented through non-judicial jurisdictions or even the actions of a law enforcement officer that does not comply with civil law. The impossibility of applying the legal provisions on prescription to cases of non-claim protection of the violated right has already been indicated in our civil doctrine. At the same time, the possibility of judicial protection of the right through the use of state coercion arises after its violation and is limited to certain terms the statute of limitations.

3. The essence of the right to non-jurisdictional protection.

The protected legal relations, regardless of whether it is implemented with the help of a competent body or independently by the right holder, includes coercive menas sanctions. Thus, protection measures and liability as types of civil sanction can usually be carried out both with the help of a competent body and out of court. The debtor's voluntary performance of a breach of duty or compensation for damages is an example of the latter. As Y.S. Zhytsynsky correctly noted, most civil law sanctions are shaped in the law as an obligation of the offender to perform particular restorative or compensatory actions due to their focus and property nature (Zhytsynsky, 1966, p. 13). Although the literature has criticized the possibility of covering a voluntary overdue obligation by sanctions (Bratus, 1973, p. 33), it cannot be accepted. The fact is that the content of the protective legal relations, which arise after the violation of regulatory law, contains the obligation of the debtor to suffer the negative consequences of the offense. Such an obligation exists from the moment of violation regardless of whether the claim is made by the managed entity or not. Therefore, it would be completely wrong to link security relations only with the use of state coercion. Coercion is a procedural method of influence, the implementation of which achieves the goal of restoring the violated right, cessation of illegal actions or other positive effect. If the statutory proteted duty is performed voluntarily, there is no need for coercion. However, the substantive result will be the same.

If the voluntary implementation of the protection and legal obligation, which arose as a result of violation of subjective substantive law, does not occur, the question arises about the application of certain means of influence to the debtor. In our civilization, the thesis according to which the existence of the possibility to ensure state coercion exercised by a law enforcement body does not deny the existence of other means of protection of the violated or disputed right is practically undeniable. As Y.K. Osipov pointed out, neither the interests of the state, nor the interests of specific subjects of law do not create the need in any case of a civil offense to apply to the bodies endowed with jurisdictional powers. The state has the right to provide the opportunity to exercise the right to the holder, establishing an appropriate framework for appropriate action (Osipov, 1973, p. 94).

There is no consensus in science as to whether there is a type of sanctioned outof-court operative influence on the violator of the exercise by the commissioner of his protection authority, which arose within the relevant protection-legal relationship as a result of the obligor's failure. Some scholars consider these actions a separate sanction that can be implemented by the person itself (Stoyakin, 1973, p. 15). In principle, we can agree with this position. Indeed, a sanction is a way of influencing an offender. As we have pointed out in previous sections of this paper, sanction is seen in the doctrine as a legal concept that encompasses 
both liability and other remedies. In this context, we can consider as a sanction the further imposition on the debtor of the obligation to reimburse the costs associated with this, to pay a penalty. These sanctions are applied in court and are measures of civil liability.

At the same time, the civil law also includes a unilateral change or termination of the legal relationship at the discretion of the creditor (Article 611 of the CCU). In this case, this protective authority within the meaning of this regulation can be exercised both as a result of a relevant claim to the court, and by independent active behavior of the managed person. It is only important that the plaintiffhas the authority to perform these actions, that is, in other words, such authority should be reflected in the law or agreement. And, although the doctrine does not end the controversy over the legal nature of such a phenomenon as prompt response to the offender (for example, V.P. Gribanov notes that these measures can not be attributed to sanctions because they are not general in nature and do not improve property state of the creditor (Gribanov, 2000, p. 34), in our opinion, these are still sanctions, moreover - sanctions in the form of civil liability, as they are listed as such in Article 611 of the CCU. Therefore, it is categorically impossible to agree with the opinion of E.O. Krasheninnikov that the measures of civil liability are always associated with state influence, and the relevant rights can be exercised only with the help of a jurisdiction (Krasheninnikov, 1990, p. 33-34).

But the inclusion of only the measures of civil liability in the concept of sanction does not exhaust its content. Among the types of material consequences of the offense - sanctions - there are also other types of influence that provide protection but do not impose additional burdens on the debtor. In particular, it is a question of restoration of the previous condition of the relation, performance of a duty in kind. Therefore, if the legislator provides the possibility of operative influence of the authorized person on the offender by individual application of liability measures, which are known to lead to a new burden on the obligated person, it is logical to give the creditor the opportunity to independently carry out a security obligation, when its implementation is to take personal action. For example, the creditor may independently choose the goods from a third party, where it is stored, if the debtor does not transfer it within the prescribed period. However, such a rule is still not widespread in the implementation of specific relationships, so we must state that the most appropriate measure of operational influence is the extrajudicial application of sanctions to the violator in the form of civil liability.
Belonging of protection rights to the right holder is authorized in the current civil legislation. It follows both from the general norm of Article 15 of the CCU and from certain norms of substantive law. The important factor is that the exercise of this protection and legal authority always occurs through the commission of active unilateral actions by the managed entity. As for the responsibilities of another party to the protection obligation - the debtor - the infringer, they consist in the passive behavior of the latter, the need to take measures of unilateral protective influence. Thus, the actions of the creditor in this situation are guaranteed (sanctioned) by law and constitute the material content of the law enforcement relationship, according to which the creditor's authority to take active action is opposed by the debtor's passive obligation not to interfere with his right.

If the measures of operative influence of a party in a civil legal relationship on the violator are recognized as one of the ways to protect civil rights and interests, then naturally they should be reflected in the main legal document governing civil relations - in the general part of CCU law. Moreover, the special rules governing certain binding relationships specify such sanctions. For example, one of the most effective means of prompt response to a breach of an obligation is a unilateral waiver of the contract (Luts, 2001, p. 68; Crome, 1900 , p. 183). Thus, the landlord has the right to withdraw from the contract and demand the return of the thing, if the tenant does not pay for the use of the thing for three consecutive months (Part 1 of Article 782 of the CCU). As you can see, the creditor party for the breach of the obligation terminates the contract by unilateral action without recourse to the jurisdiction. This is the difference between this response and the termination of the contract at the request of the landlord (Article 783 of the CCU). In the latter case, the decision to terminate the contract is made by the court.

Examples of operational sanctions are often found in special rules of law governing private law. They can be represented by the refusal of the contract or the acceptance of improper performance (for example, Articles 678, 684, 848, 849 of the Civil Code of Ukraine, Articles 268, 270 of the Civil Code of Ukraine), the transfer of a counterparty that does not properly perform monetary obligations, to prepay, limit or terminate the provision of utilities and other services to consumers who violate the privileges of using them, etc. But, again, in general, there is no indication of such operational protection in the Civil Code.

It may not be necessary to introduce rules on operational measures of influence in Chapter 
3 of the Civil Code, as it specifies the general methods of legal protection inherent in protection relations in any area of civil law regulation. Operational influence is used only in the implementation of security interactions, which are formed as a result of breach of obligation. In addition, the parties to the obligation may apply operational measures to the counterparty only when they are endowed with the necessary powers under the terms of the contract or by law. Thus, the operative influence on the violator of the right should be qualified as a special way of protection of civil rights, which derives from the obligatory legal relations. Therefore, it must be specifically reflected in the main act of civil law, for example, in Chapter 51 of the CCU. Moreover, this specification should relate not only to the definition of such tools and instructions on how to implement them, but also to determine the grounds, timing and procedure for its application.

4. Features of temporal regulation of relations on operational protection.

If the normative act or agreement of the parties to the legal relationsh prescribes the possibilities, grounds and nature of the operational sanction to the defaulting debtor, the legality of their application to the counterparty in breach of the obligation, as a rule, does not cause discussion. In this case, the arbitrary interpretation of the creditor's right in such a case is illegal. Thus, if, for example, the contract defines the offense for which restriction can be applied, then, in case of legal fact - commission of such a violation -exercise of the creditor's right is lawful. Thus, according to the current Ukrainian legislation, the creditor is the owner of a certain protective subjective right to take operational measures as a unilateral action against a faulty counterparty. Guided by the statutory or contractual scope of powers that make up the content of this right, the entity may take actions that lead to the implementation of the authority enshrined in law. At the same time, the duty of the entitled person is not to go beyond the limits set for the most subjective right. This applies equally to the content of the right itself and the implementation of measures for its implementation. Undoubtedly, the content of subjective law includes the term of its existence.

However, as already mentioned, the legislation generally does not set deadlines for operational protection measures, and this, in our opinion, is its disadvantage. Based on the principles of pragmatism and reasonableness in the implementation of substantive and legal interactions in society and, given the regulatory imperfections of this segment of regulation, the issue of timeliness of operational measures to influence the offender, we have devoted several special works (Guyvan, 2011, p. 95-102; Guyvan, Monograf., 2014, p. 384-408). One of the main conclusions obtained from these studies is that the duration of operational measures can not be unlimited, and even more so, not set by the lender at its discretion. We are convinced that the expediency of such sanctions (and hence the period of application) should be limited to the duration of the offense, this is the duration of the violation and can be recognized as a period for the application of operational non-jurisdictional measures, unless otherwise specified in the regulation. The relevant rule should be reflected in current civil law.

In the same cases, when the procedure and mechanism of application of certain operational sanctions to a defective counterparty is defined in a special legal act (this usually applies to the provision of various utilities and fixed in the relevant Rules), the entitled party to exercise the right to unilateral action must follow the procedure. of a certain duration provided by law. Moreover, this legislation does not allow the immediate application of these measures after the offense, postponing the implementation of this protection right until a certain point. In some cases, the application of operational measures requires repeated violations of the same right (systematic violation). It is clear that there must be some (reasonable) time between violations. After all, these one-time but repeated violations cannot be qualified as ongoing.

In our opinion, such an approach is justified: the legislation should contain a certain deferral period, intended for the violation to be "ripe" and the protective legal relationship regarding the application of operational influence on the violator to acquire its ability. As for the length of the period during which an operational sanction can be applied, then, again, the law usually does not contain any reservations. Strictly speaking, there is no legal requirement that would limit the period of application of the operational sanction provided for in Art. $615 \mathrm{CCU}$ (unilateral withdrawal from the contract), say one or three years. Moreover, the period of application of operational measures can not be linked to the statute of limitations. In our opinion, this is the situation when, say, the landlord withdraws from the contract in 2021, because the tenant in 2016 for three months in a row did not pay for the use of property, although it can not be considered illegal, but it is illogical. Thus, if we talk about the timing of the operational impact on the violator as a form of protection of rights (Luts, 1993, p. 27), then only in the understanding of the minimum reasonable duration of the operational actions themselves. 


\section{Conclusions.}

It is proposed to introduce relevant amendements in the civil legislation (e.g., to set out in a separate article an approximate non-exhaustive list of statutory powers of the creditor in case of breach of obligation by the debtor, as it is found in Art. 236 of the Commercial Code of Ukraine). However, the indication of the existence of such material interactions should not be limited to adjustment. The limits of realization of the specified powers should be established in the same article. In particular, with regard to the temporal regulation of the mechanism for exercising these rights, it is necessary to point out the need to take relevant preventive actions within a reasonable period from the moment of detection of the violation and the limited duration of these powers. As for the duration of the human rights actions, fixed periods for the application of operational influence on the violator may be established in special norms for certain legal relations. A general rule should contain a note that the term of the relevant protected powers should be reasonable but, in any case, not to exceed the duration of the violation.

\section{References:}

Antonyuk O.I. (2004). Pravo uchasnykiv tsyvilnykh pravovidnosyn na samozakhyst [The right of participants in civil relations to self-defense]. Candidate's thesis. Kharkiv (in Ukrainian).

Basin Yu.G., Didenko A.G. (2003). Operativnyye sanktsii kak sredstvo zashchity grazhdanskikh prav. [Operational sanctions as a means of protection of civil rights]. Izbrannyye trudy po grazhdanskomu prazu. Selected works on civil law. (pp. 419-423). SPb: Legal Center Press. (in Russian).

Bratus S.N. (1973). Spornyye voprosy teorii yuridicheskoy otvetstvennosti. [Controversial issues of the theory of legal responsibility]. Sovetskoye gosudarstvo i pravo - Soviet state and law. 4. 27-35. (in Russian).

Cherepakhin B.B. (1964). Iskovaya davnost v novom sovetskom grazhdanskom zakonodatelstve. [Statute of limitations in the new Soviet civil law]. Aktualnyye voprosy sovetskogo grazhdanskogo prava - Current issues of Soviet civil law. (pp. 71-93) Moscow: Jurid. lit. (in Russian).

Crome, C. (1900). System des Deutschen Buergerlichen Rechts. Bd. 1. TuebingenLeipzig, 452 s. (in Germany).

Dobrovolsky A.A. (1965). Iskovaya forma zashchity prava. [Claim form of protection of rights]. Moscow: Moscow Publishing House. University, 1965. (in Russian).

Eliseikin P.F. (1975). O ponyatii i meste okhranitelnykh otnosheniy v mekhanizme pravovogo regulirovaniya. [On the concept and place of protective relations in the mechanism of legal regulation]. Yuridicheskiye garantii primeneniya prava i rezhim sotsialisticheskoy zakonnosti. - Legal guarantees of the application of law and the regime of socialist legality. Yaroslavl, 1. 5-10. (in Russian).

Gribanov V.P. (2000). Osushchestvleniye i zashchita grazhdanskikh prav. [Exercise and protection of civil rights]. Moscow: Statut, (in Russian).

Guyvan P.D. (2011). Deiaki pytannia svoiechasnosti zastosuvannia okhoronno-pravovykh operatyvnykh zakhodiv. [Some issues of timeliness of application of security and legal operational measures]. Pravo ta upravlinnia. Elektronne naukove fakhove vydannia / Law and Management. Electronic scientific professional publication. 1, 95-102. Retrieved from: www.nbuv.gov.ua/e-journals/prtup/ index.html. (in Ukrainian).

Guyvan P.D. (2014). Teoretychni pytannia strokiv u pryvatnomu pravi. [Theoretical questions of terms in private law]. Monograph. Kharkiv: Pravo. (in Ukrainian).

Guyvan P.D. (2014). Strok subiektyvnoho materialnoho prava yak kharakterystyka yoho zmistu [The term of subjective substantive law as a characteristic of its content]. Pidpryiemnytstuo, hospodarstvo i pravo - Entrepreneurship, Economy and Law. 8. 19-23 (in Ukrainian).

Guyvan P.D. (2021). Faktor chasu v tsyvilnykh materialnykh pravovidnosynakh. Osoblyvosti okhoronno-pravovoho zoboviazannia. [The time factor in civil substantive legal relations. Features of the security obligation]. Naukovyi visnyk Uzhhorodskoho natsionalnoho universytetu. Seriia : Pravo. - Scientific Bulletin of Uzhhorod National University. Series: Right. 64. 107-111. (in Ukrainian).

Guyvan P.D. (2004). Pytannia vidpovidalnosti storony za dohovorom za nenalezhne zastosuvannia sanktsii do kontrahenta. [The issue of liability of the party under the contract for improper application of sanctions to the counterparty]. Pravo Ukrainy - Law of Ukraine 6, 36-39. (in Ukrainian).

Karkhalev D.N. (2009). Okhranitelnoye grazhdanskoye pravootnosheniye: monografiya. [Protective civil legal relationship: monograph]. Moscow: Statut. (in Russian).

Kostruba A. (2014) Tsyvilne pravovidnoshennia v mekhanizmi pravovoho rehuliuvannia. [Civil legal relationship in the mechanism of legal regulation]. Visnyk Natsionalnoi akademii pravozykh nauk Ukrainy - Bulletin of the National Academy of Legal Sciences of Ukraine № 1 (76). 112-120. (in Ukrainian).

Krasheninnikov E.A. (1990). Sanktsii. prinuzhdeniye i otvetstvennost v grazhdanskom prave. [Sanctions, coercion and responsibility in civil law]. Yuridicheskaya otvetstvennost: obshchiye prob- 
lemy i otraslevyye osobennosti. Dalnevostochnyy gosudarstvennyy universitet. Tezisy dokladov mezhvuzovskoy konferentsii molodykh uchenykh - yuristov. - Legal responsibility: general problems and industry features. Far Eastern State University. Abstracts of reports of the interuniversity conference of young scientists - laweyers. Vladivostok: Dalnevost Publishing House. University, (pp. 32-35). (in Russian).

Lyashevska L.I., Khlystun O.V. (2018). Pravova pryroda samozakhystu tsyvilnykh prav yak zasib protydii tsyvilnym pravoporushenniam. [The legal nature of self-defense of civil rights as a means of combating civil offenses]. Naukovyi visnyk Uzhhorodskoho natsionalnoho universytetu, Seriia PRAVO - Scientific Bulletin of Uzhhorod National University, Series LAW. Issue 51. Volume 1. 110-114. (in Ukrainian).

Luts V.V. (2001). Kontrakty u pidpryiemnytskii diialnosti. [Contracts in business]. Kiiv: Jurinkom Inter, (in Ukrainian).

Luts V.V. (1993). Stroky zakhystu tsyvilnykh prav. Konspekty lektsii zi spetskursu. [Terms of protection of civil rights. Abstracts of lectures on a special course]. Lviv: LSU. (in Ukrainian).

Osipov Yu. K. (1973). Podvedomstvennost yuridicheskikh del. [Jurisdiction of legal cases]. Sverdlovsk, (in Russian).

Stoyakin G. Ya. (1973). Mery zashchity v sovetskom grazhdanskom prave. [Protection measures in Soviet civil law]. Extended abstract of candidate's thesis. Sverdlovsk. (in Russian).

Zhytsynsky Y.S. (1966). Sanktsiya sovetskogo grazhdanskogo prava. [Sanction of Soviet civil law]. Extended abstract of candidate's thesis. Kiiv. (in Russian).

\section{Петро Гуйван,}

кандидат юридичних наук, заслужений юрист України, професор, Полтавський інститут бізнесу, вулиия Сінна, 7, Полтава, Україна, індекс 36000, lazјјur01@rambler.ru

ORCID: orcid.org/0000-0003-3058-4767

\section{СУТНІСНІ ХАРАКТЕРИСТИКИ НЕЮРИСДИКЦІЙНИХ СПОСОБІВ ПРАВОВОГО ЗАХИСТУ: ТЕМПОРАЛЬНИЙ АСПЕКТ}

Анотація. Метою роботи є вивчення питання про сутнісні та темпоральні ознаки неюрисдикційних способів захисту порушеного цивільного права; встановлення певних часових критеріїв охоронної здатності права, відмінної від часу реалізації позовного домагання. Методи дослідження. Використано загальнонаукові та спеціально-наукові методи пізнання, які дають змогу розглянути темпоральні чинники як елементи суб'єктивного матеріального права і правовідношення загалом та визначити іх місце в системі захисного механізму цивільного права. Результати. Досліджено основні доктринальні концепції стосовно принципів вчинення таких заходів впливу на правопорушника, як самозахист і застосування оперативних захисних засобів. Встановлено, що ці неюрисдикційні способи мають таке саме юридичне забезпечення, як і звернення особи до суду. Це повноваження являє собою певну сукупність дій носія порушеного суб'єктивного цивільного права, спрямовану на припинення порушення або інший захист без звернення до компетентного органу держави. Однак у темпоральному відношенні правове унормування має різний характер, для визначення строку захисту в такому характері позовна давність не застосовується. Для самозахисту важливо, щоб він відбувався в момент правопорушення, а для оперативних санкцій (позаяк закон у більшості випадків не встановлює час їх здійснення) необхідно керуватися загальними принципами добросовісності та розумності. У цьому сенсі розглянуті окремі аспекти застосування таких оперативних дій, як відмова від договору, одностороння зміна чи припинення правовідношення за волевиявленням вірителя. Важливо лише, щоб віритель мав повноваження на вчинення вказаних дій, тобто ця правомочність має бути відображена в законодавстві або угоді. Також необхідно, щоб вказані дії перебували в часових межах адекватного реагування. Висновки. Унаслідок розгляду у статті зроблено висновок, що часові межі здійснення вказаних правомочностей необхідно встановити нормативно. Зокрема, у правовому акті варто вказати на необхідність вчинення певних попереджувальних дій упродовж розумного строку від моменту виявлення порушення та на обмеженість тривалості існування зазначених повноважень. Час відповідних охоронних повноважень має бути розумним, проте не перевищувати тривалість порушення.

Ключові слова: розумний строк, позовна давність, оперативний захист. 